\title{
The early Latin Church Fathers on Herod and the Infanticide
}

M J Mans

Department of Ancient Languages (Section Latin)

University of Pretoria

\begin{abstract}
Since the views of the early Latin Church Fathers on Herod and the carnage at Bethlehem have been neglected by modern scholars, this study is an attempt to discover and interpret their opinions on the notorious king and this tragic event. Apparently, the main aim of the Latin Church Fathers was to present Herod's heinous deed in the worst possible light, and to exalt the Innocents to the ranks of the martyrs.
\end{abstract}

\section{INTRODUCTION}

The notion of massacring infants was familiar in ancient Palestine (Langer 1974:355, 363). There is ample evidence in various books of Holy Scripture and elsewhere that children, infants, new-borns, even unborn babies were killed for various reasons: as a restrictive measure to depopulate an area or as a retaliatory measure (Ex 1:15-17; 11:46); or as punishment which God's own people brought upon themselves by their disobedience, faithlessness and wickedness (Is 13:16,18; Ezk 9:5-6; Jr 13:14; 2 Ki 8: 12; Hs 14:1; Nah 3:10). In one of the so-called 'revenge psalms', Ps 137:9 (Loader 1979:169-171), we find the most gruesome words: '... happy is he ... who seizes your infants and smashes them against the rocks' (cf Is 13:16,18; Jr 13:14; Sen HercFur 1002ff; Sedul SolOrtOrd 37-40) ${ }^{1}$. Both the exposure of children and more active forms of infanticide were widely practised and were not heavily censured in either Greece or Rome where infants were not considered sacrosanct (PI Resp 5.460sqq, 7; Aristot Pol 2.6-7; 7.4.16; 14.10; Cic Leg 3.8.19; Sen Ira 1.15.2; Suet Calig 5; Liv 27.37.5-6; Dion Hal AntRom 2.15.1-2; 2.26-27; Epict Diss 1.23; Dig 25.3.4; 28.2.11; Gell 5.19; Quint Décl 306; Plut AmorProl 5; Plin 10.65-66,72; Tooley 1983:16; Langer 1974: 354-355,362-363; Harris 1994:4,5,15; Verg Aen 6.428-430; Westermarck 1906-8:408-411). In fact, such practices were even accepted sources of humour in Greek comedy, for instance in Menander's 'The Girl from Samos', and 'The Arbitration' (Williamson 1978:69, 75). 
However, by the first century A D, Philo expressed strong disapproval of infanticide (SpecLeg 3.110-119). In the second century, Tertullian mentioned laws forbidding the killing of children (Nat 1.15.3). Nevertheless, infanticide (and abortion) were only canonically condemned by the Church (canons 63 and 68) in the fourth century, and lifelong excommunication was then imposed for this crime by the Church Council of Elvira in ca 305/306 AD (Ferguson et al 1990:4, 297-298). It was the Christian emperors of the fourth century who, although they were initially hesitant, first took legal steps to prevent child-exposure and infanticide in response to their religious concerns (Harris 1994:19)2. Actual secular legal penalties were only imposed in 374 by Valentinian and his fellow Augusti, Valens and Gratian (Harris 1994:20,21; Langer 1974: 355, 363). On 7 February 374, the same year (Codex Theodosianus 9.14.1), it became a capital offence to kill an infant (Harris 1994:19, 21, 22) ${ }^{3}$.

Generally speaking, most of the early Fathers of the Church, who made mention of it, disapproved of the Bethlehem massacre. The Latin Fathers were no exception in this regard. This communication shows that they were determined to judge Herod for the slaughter of the Innocents. It is evident that they vehemently, and indignantly, condemned this abominable and unjustified act, and that they, as modern readers would expect, expressed sincere pity for the innocent little victims of this heinous crime.

Consequently the following question arises: who was the first martyr for Christianity? Was it Stephen, the victim of stoning in Acts 7:57-60, or an even better candidate, Jesus Himself? Or some anonymous infant in Bethlehem (Maier 1975:7)? Inevetibly, attention will be given in this study to the important question whether the early Latin Church Fathers regarded the inocent children as martyrs, and to an equally important one, that is whether they considered the infants to be the very first martyrs prior to the founding of the Church.

The slaughter of the Innocents has beeen drenched with doubt from various quarters: many ancient historians, church historians, biblical commentators, biographers of Herod, and critical scholars have questioned its historicity (Maier 1975:7). Have the Latin Church Fathers also called this episode into question? An answer to this question may be provided by the evidence presented below. It would also be interesting to know whether the Latin Fathers of the Church noticed and utilized the homiletic impact of the infant massacre.

The views of the early Latin Church Fathers from the third to the seventh centuries on Herod and the slaughter of the Innocents have been sadly neglected by modern scholars such as historians, moralists and theologians (Maier 1975:10; Langer 1974:353365; Westermarck 1906-1908:408-411; France 1979:89-120; Tupper 1991:399-418; O'Brien Steinfels 1983:492-493). Pagan classical sources, Greek as well as Latin, 
were definitely used by these scholars as confirmation of their statements and opinions but, unfortunately, the Latin Church Fathers were not consuited by them. Their views could possibly shed more light on the interpretation of this gory event, also to the benefit of modern scholars. This study, inspired by the problematic verb allentabit in verse 81 of the anonymous hymn Psalmus Responsorius (Mans 1993:72-79)4 attempts to discover and interpret their opinions on the notorious Herod and this important event synoptically, chronologically and more comprehensively than has hitherto been done.

\section{ON HEROD}

For some reason or other, silence reigned in Latin patristic works from the first century A D onwards on Herod and his involvement in the slaughter of the Innocents. One of the first Latin Patristic authors to break this silence was none other than the fourth century Christian poet, Prudentius, who accused Herod of insanity (Cath 12.97) of wickedness and criminal behaviour (Cath 12.133-144; TitHist 29), and of being an insecure monarch (Cath 12.93; Aug Faust 22.62). Optatus of Milevis (North Africa) (in the second half of the fourth century) expressed his abhorrence of Herod's slyness and insanity (NatSanctInnoc 289.2 PL Suppl 1). Optatus was convinced that the injustices of all persecutors are condemned and all their plans exposed through the persecutor Herod (NatSanctInnoc 291.7 PL Suppl 1). Augustine execrated Herod's cruelty in his Contra Faustum 22.62. He also expressed the following vain wish in his Enarrationes in Psalmos Ps 48: 'would that Herod too had adored the King with the Magi' (En 47.5.19; FulgRusp Serm 4 PL 65 734).

Augustine, well aware of the homiletic impact of a figure such as Herod, used the example of Herod, dethroned by Christ, and losing his sovereignty, and the king's mad rage to deter Christian believers from falling into the madness of anger due to fear, and to encourage Christian believers to strive for the Kingdom of Heaven rather than for an earthly kingdom (Traclo 115.2 PL 35; Serm 375a PL 39 1668). Another fourth century author, Lucifer of Cagliari (Calaritanus), implicitly labelled Herod an insane executioner (Quia absentem nemo debet iudicare nec damnare 2.3.40) and accused the king of unjust action against the babies of Bethlehem (Quia absentem nemo debet iudicare nec damnare 2.3.49). St. Jerome focused on Herod's malice and compared him to a sly fox (Hier CommIs 3.50; CommEz 4.13.13). St. Augustine, on the other hand, represented Herod as an earthly little fox, perturbed by the birth of Christ, the lion of Heaven (Serm 375a). Pseudo-Jerome and Apponius believed that the king was used as Satan's instrument in the slaughter of the Innocents (PsHier ExpHierCant 1; Appon ExpCantCantic 4.617). Optatus joins forces with these authors, asserting that the devil that possessed Herod was discouraged and deplored the fact that the Christian Church 
had been snatched away from his jaws and united with God (OptatusM Serm NatSanctInnoc 2). The strongest condemnation and the most damning characterization of Herod, however, were those of the fifth century author, Chrysologus. He-described Herod in no uncertain terms, and very elaborately, as a murderer of helpless infants, as a robber breaking up families (Serm 127.17), as an unscrupulous, criminal, insane man, caught up in his own snares, as a commander-in-chief of evil, as a military bully, and as a spiritually blind king, slaughtering innocent children while in search of the new-born Christ, to name but a few of these sharply rebuking characterizations (Serm 152). Fulgentius of Ruspe (Ruspensis), in the fifth to the sixth century, described Herod as deceptive, cruel and sly (Serm 4 PL 65 734). He also echoed Augustine's futile wish: if only Herod could have worshipped the Child as the Magi 5 had done! (Serm 4 PL 65 734). Sedulius referred to Herod as a tyrannus, that is a cruel nuler (SolOrtOrd 37-40). Leo Magnus also mentioned his cruelty and insanity, and regarded the murder of two year old and younger infants as ill-judged (Trac 32 \& 36).

In the seventh and eighth centuries Bede also condemned Herod's unscrupulous slaughter of innocent children, and at the same time he informed his audience that the king was also to be heavily censured for not accepting the good faith (certainly not the Christian faith!) and confidence of the Magi in their search for the Christ (ProvSalom 3.2.21) [See endnote 5]. Another interesting fact in connection with persecutors like Herod, is that, according to Bede, Herod's death, not long after the Infanticide, signifies that all persecutions launched against the Church were bound to be avenged by the death of the persecutors, and that their death then restores peace to the Church (HomEv 2.10).

In the main, the views of the early Greek Church Fathers on Herod agree to a remarkable degree with those of the Latin Fathers. They shared a common hatred for Herod since one and all presented him in the worst possible light. The Greek Fathers also accused Herod of insanity (BasSel Or 37.390.189B.2; Romanos On the Massacre of the Innocents strophe 7.13; Eus $H E$ 1.8.6), of confusion (Romanos On the Massacre of the Innocents strophe 4), inhumanity, cruelty (BasSel Or 37.390.189B.2); Chrys Hom 9; Romanos On the Massacre of the Innocents strophe 1; TheophCer Hom 52 SanctInnoc 919), and violence (Chrys Hom 9), and execrated his arrogance, lawlessness, wickedness (Romanos On the Massacre of the Innocents strophe 10; TheophCerHom 52), and injustice (Chrys Hom 9). In the eyes of Romanos the Melodist, for instance, he was not only a slayer of infants (On the Massacre of the Innocents strophe 7), but also a beastly (strophe 13) and frightened king (strophe 2; GrNyss DiemNatChr PG 46). Eusebius was firmly convinced that Herod, both physically and mentally a' very sick man, torn by great agony, paid a just penalty for his deeds, murdering the children of Bethlehem: his illness, a scourge sent from God, drove him to his death (Jos quoted by Eus HE 1.8.5-16; Chrys Hom 9.3). 


\section{ON THE INFANTICIDE AND THE INNOCENTS}

The way the early Latin Patristic authors saw the Infanticide itself and the innocent victims of Bethlehem, must now be examined in greater detail. The noticeable, and rather surprising silence on the Infanticide kept by the first century historian, Josephus ${ }^{6}$ (Maier 1975:8-9) was broken by the third century Latin author Cyprian, who indeed regarded the innocent infants slain by Herod as martyrs (Cypr Ep 56 PL 4 pars 1.359; Iren Haer 3.16.4 PL 7 923-924). From a literary point of view, however, the fourth century Latin Christian author, Prudentius (as can be expected of a poet), made the most of the Infanticide: his version was more elaborate, much more gruesome and imaginative, compared to contemporary Latin patristic authors' more theologically oriented renderings. The reader finds a dramatic and vivid, if not too realistic, emotive description of the violent event, in his twelfth Cathemerinon hymn (verses 93-135). The Prudentian version furnishes the audience with no less than three methods of killing the babes: (i) by the sword and poniard, (ii) by dashing their heads against rocks, a method also mentioned by Seneca and Sedulius (Sen HercFur 1002sqq; Sedul SolOrtOrd 37-40) and (iii) by drowning (Prud Cath 12.109-125), a method confirmed by Tertullian and Seneca (Prud Cath 12.109-125; Sen Ira 1.15.2; Tert Nat 1.15.3). Prudentius was perhaps the first Latin Christian author to describe the children as flores martyrum ('martyr-flowers'), flowers of martyrdom, that is Christ's first offerings (Cath 12.125), but he was not the first Latin Church Father to regard them as martyrs. As we have indicated above, his predeccesor, Cyprian, already referred to them as martyrs. Moreover, a Greek Church Father, Irenaeus, already equated the murdered infants with martyrs as early as the second century (Cypr Ep 56 pars 1.359sqq; Iren Haer 3.164). According to Prudentius, immortality was bestowed on the thousand little ones of Bethlehem (Perist 10.725-742). Regarding the infants' martyrdom, St. Augustine not only shared Cyprian's and Prudentius' personal conviction that the murdered infants were martyrs, but also added that it was not without reason that the Church exalted the children slain by Herod to the honourable ranks of martyrs (Aug $E p$ 166: LibArbit 3.23; Aug En 47.5).

In his Sermo 199 St. Augustine obviously utilized the homiletic significance and power of a theme such as the Infanticide. By means of an antithesis, that is an unreasoning immature infant versus a rational adult, he stressed the following message: even children who were not yet capable of confessing Christ could suffer for Him, but adults who could point out the city of His birth did not accept the truth preached by Him. St. Ambrose beleived, however, that, although these infants were reasonless they, nevertheless, confessed God for whose sake they died (Ambr ExLuc 2.49). Furthermore, Augustine intimated that Christ showed 'how innocent and lowly were the 
sort of people who would, in turn, die for Him' (Serm 202; Serm 375a). St. Augustine exalted their innocence as follows: 'Happier far the ignorance of the babes whom Herod in his terror persecuted than the knowledge of those whom he in his anxiety consulted' (Serm 199 PL 38 1027.42). Innocence, according to Optatus of Milevis, always suffers for the sake of truth, and holy blood was shed in the past with impunity in order to be more severely condemned (NatSanctInnoc 5). St Jerome believed that the infants were rewarded for shedding their blood for Christ with a place in the Heavenly Kingdom and with glorified bodies (HieremProph 6 CSEL 391.10). His contemporary, Optatus, stated that the infants knew Paradise before their secular life on earth. He consequently considered the death of these innocents to be glorious and declared that even before they were Christian believers, Herod's killing of them had made martyrs of them (NatSanctInnoc 3.4.289; Caesar Serm 222.2). Sixth century Caesarius in similar terms echoes Optatus as follows: 'They acquired the dignity of eternal life before they received enjoyment from the present one' (Serm 222.2). Chrysologus, however, was convinced that the infants' martyrdom was not merited or earned but came only through the grace of God (Serm 152). Augustine asserted that Christ sent these firstlings to his Father. He also maintained that the age of two years of some of the babes of Bethlehem signifies the two precepts upon which the whole Law and the Prophets depend, that is love the Lord your God with all your heart, soul, and mind; love your neighbour as yourself (Serm 375a; Serm 202; Mt 22:35-40). Here, in my opinion, Augustine, contextually, sadly fails to communicate a purposeful message to his reader. Obviously the number, two, is dragged in by the hair, unless our author implicitly uses one of the two precepts, that is love your neighbour as yourself, with the ultimate intention of execrating Herod's killing of the infants!

In consequence of Matthew's matter-of-fact narrative of the event, apparently neither interpreting nor judging it (O'Brien Steinfels 1983:493), Augustine emphasized that although the Infanticide is merely mentioned in Chapter 2:16, without being condemned, this clearly does not mean that we should condone it, but that we should pass judgement on it ourselves (Faust 22.62; cf. Chrom Serm 10.54).

Chromatius of Aquila (late fourth to early fifth centuries) referred to the rigliteous and the prophets, using the image of bullocks and prize calves, butchered because they predicted that the Incarnated Christ would come to this world and die. In his opinion these 'fattened cattle', destined to be killed, symbolize the infants who were slaughtered by Herod since they were worthy of dying for the sake of Christ (Chrom TracMatt 6.63). In accordance with his predecessors Chromatius also claims that on account of their death these innocent infants became the first martyrs of the Church (TracMatt 6.63). Furthermore, in another sermon, he referred to the children of Bethlehem as the 
eyes of the Church, washed in purifying milk. This is undoubtedly an allusion to the martyrs and prophets of the Church who were regarded as precious eyes in the body of the Church, and were immersed and washed in purifying milk. In a spiritual and baptismal sense, then, this must be regarded in the sign of purification and of admission to the Church (Serm 14).

During the fifth century, the adoration of the Innocents seems to have gained momentum. Leo Magnus (440-461 A.D.) was convinced that Christ crowned even the infants with the glory of martyrs (Trac 36). He also beleived that the death of the infants was an adumbration of all martyrs (Trac 38.1). Apponius maintained that as a result of the violent death of the infants, (other?) flowers of innocence made their appearance on earth (CantCantEx 4). Quodvultdeus used the image of a great crop for the Church not only in the form of the martyrs of the Church, but also in the form of the infants killed by Herod (PromissPraedDei Pars 1.32), and of the precious seeds of faith being sown. According to him, Christ gave immortality and life everlasting to the infants killed for His sake (IudPagAr Serm 4.10; PromissPraedDei 2.9; Prud Perist 10.725-742; Iren Haer 3.16.4). Furthermore, Quodvultdeus firmly believed that the multitude of dying infants gained innumerable victories over Herod (Serm 2; Symb 2.4). Fulgentius (ca 467-533 AD) supported this view by saying that Christ permitted Herod to kill the children in order that they could triumph over this cruel king by means of their premature death (Serm 4 PL 65 734sqq). He added that Herod unwittingly made martyrs of the infants by means of his cruelty. Fulgentius was also convinced that their death was not in vain because they were saved by virtue of Christ's propitiation (Serm 4 PL 65 732).

The following question perplexed the minds of fifth century Chrysologus and the Greek Fathers, Irenaeus and Chrysostom: why did Christ, the King of Heaven, desert the infants whom He knew would be killed for His sake? Chrysologus, in accordance with the views of these two Greek Fathers of the Church, maintains that Christ did not abandon His little soldiers, but graced them with martyrdom and sent them ahead to His kingdom to possess Eternal Life (Serm 152; cf Iren Haer 3.16.4; Chrysol Hom 9; TheophCer Hom 52.919.355).

The sixth century author Caesarius of Arles echoed the fifth century sentiments with regard to these little martyrs. In fact, he even referred implicitly to the twelfth Cathemerinon hymn of fourth century Prudentius, specifically stating that they are rightly called 'the blossoms of martyrdom' (CaesarArel Serm 222.1.2). Caesarius argued that it is therefore proper to give ceremonial honour to the infants ${ }^{7}$, and not to grieve over them, but to rejoice with the greatest exultation (Serm 222.1.2). Suffering the cruelty of King Herod and the death of the infants allowed Bethlehem to offer a multitude of peaceful, sinless infants to God. Death guaranteed the start of their glory (Caesar Serm 222.1.2; EusGall Hom 11.27sqq) ${ }^{8}$. 
The Itinerarium Antonini Placentini (560-570 A D) is, to my knowledge, the only Latin patristic source suggesting that the infants were laid to rest in the same grave (AnonAntonPlac Itiner CSEL 178 \& 209). The latter possibility of a mass grave must obviously be questioned, and perhaps even be rejected as an improbability.

Although the early Greek Fathers concur with their Latin counterparts of the early Church in their judgement and abhorrence of the Infanticide, they undoubtedly, from a literary point of view, also differed noticeably from the Latin patristic version of this occurrence in that they revealed a strong tendency towards 'ekphrasis', that is a detailed, vivid, and imaginative description which, in most instances, proves to be an emotive reconstruction of this tragic event, full of emotion and pathos, teeming with gory detail and realism, depicting, in most cases, a scene of utter confusion (Iren Haer 3.16.4; GrNyss NatChr PG 46 1143-1146; BasSel Or 37; JnEub SanctInnoc; TheophCer Hom 52 PG 132 917-928; GrNaz Or 28; Chrys Hom 9; Matt 2:16; Romanos On the Massacre of the Innocents). Consequently, violence is stressed more frequently in the Greek representation of the Infanticide than in the Latin Fathers' version, with the exception of that of Prudentius (GrNyss NatChr PG 46 1144-1146; BasSel Or 37 189.2-193.4, col 390-395; Romanos On the Massacre of the Innocents; IoEub SanctInnoc; TheophCer Hom 52 922-923; Prud Cath 12.93-128). [It seems as if the Latin Fathers were more inclined to exegesis].

In an attempt to present Herod's heinous deed in the worst possible light, and to rally Christian believers round them, to indicate solidarity with their audience, the Latin Church Fathers, unlike their Greek counterparts, exaggerated the numbers of infants killed, using large numbers. The Vulgate refers to omnes pueros, that is 'all the boys', and most of the Latin Fathers, in accordance with classical tradition, used vague terms such as 'so many' (Aug ConEv 1.6.9; 2.11.24; Traclo 31.2; 1.13; Faust 22.62; 1.15; FulgRusp Serm 4.734 PL 65; Beda ExLuc Prol 1.192; EusGall Hom 11.1.52; Vereclunc CommCantEccl 15.1.5; BasSel Or 37.398.194), 'many', 'very many' (Aug ConEv 2.11.24; Serm 373 PL 39 1667; Quodvultdeus Serm 3 Symb 3.4), 'thousands, many thousands' (Hier CommIs 3.7.15; EusGall Hom 11.1.20; CaesarArl Serm 22.1.10; Prud Perist 10.725-742; Sedul SolOrtOrd 37-40; Quodvultdeus Serm 3 Symb 3.4), 'a multitude (of)' (Quodvultdeus Serm Symb 2.4, 1.55; Anon QuaestGlosEv 1.200; Optat IsM NaSanctInnoc 3), or 'innumerable' (Prud TitHist 29.113). According to present scholarly estimates, however, the actual number of infants killed was between twenty and twenty-five, if that many (Maier 1975:8; Tupper 1991:409-410). 
These estimates seem to be in line with the estimation of The Greek Father, Basil of Seleucia. It is significant that the latter uses the word 'perpaucos', that is 'very few' (BasSel Or 37 398.194). Estimates of the population of Bethlehem during Herod's reign seldom exceed 1,000 (France 1979:114; Tupper 1991:409-410). Some sources even put it as low as 300 (France 1979:114),

\section{CONCLUSION}

On the basis of the evidence presented, we can infer that the early Latin Fathers of the Church undoubtedly regarded the children of Bethlehem murdered by Herod as Christ's first martyrs. According to the Latin patristic authors, however, the death of the Innocents was not in vain, because they were saved by the grace of God.

No evidence was found that these authors questioned the historicity of the carnage at Bethlehem.

Some of the Latin Fathers, such as Augustine and Chrysologus, fully realized the homiletic impact of a theme such as the Infanticide. Therefore they applied it effectively, not only to communicate the message of the Gospel to their audience, but to enable them to identify themselves with the ideas propagated and prescribed.

Although some of the Latin Church Fahers only paraphrased or quoted Matthew 2:16 without explicitly judging the events recorded, others, more comprehensive and aggressive in their interpretation of the event, levelled vehement accusations and condemnations against Herod, while, more importantly, in the same breath, almost triumphantly, they exalted the Innocents to the honourable ranks of the martyrs.

\section{Endnotes}

1 Although weapons were also used to kill children, the gruesome method of smashing babies' heads against a rock, or two babies against each other, was a well-known measure not only in ancient Palestine (Ps 137:9; Is 13:16,18; Jer 13:14), but also in ancient Rome (Sen HercFur 1002sqq; Sedul SolOriOrd 37-40).

2 The edict of Constantine, in its transmitted form, later included in the Theodosian Code of 438 A D, intended to discourage parricidium, or rather one form of parricidium, that is the killing of new-born babies by their parents (Harris 1994:19).

3 Although the vitae ac necis potestas was effectively dead at the beginning of Constantine's reign, as CodTh 9.15.1 of 318 A D indicates (Harris 1994:21; Langer 1974:355,363), child-exposure, nevertheless, was still not yet legally parricidium by 331 A D (Harris 1994:20).

4 This study was also inspired by the problematic verb allentabit, used in connection with the Infanticide in verse 81 of the anonymous hymn Psalmus Responsorius (Mans 1993:72-79) where it obviously means 'he killed/destroyed' or 'he gave orders to kill (them)'. 
5 T S Elliot in the 'Journey of the Magi' is aware of the Magi's dilemma: educated in another religion, they followed a vision, but the new religion is too young to offer them an answer, and their search continues.

6 First century Josephus, the Jewish historian, is undoubtedly the chief source for any information on Herod, but he does not mention the Infanticide in Bethelehem! According to Maier he probably never even heard of so local an event: Furthermore, he claims that Josephus had so many horrifying things to report about Herod that he might not have ranked this event important enough for inclusion in his work on the king's life: as already mentioned above, the actual number of victims is estimated between twenty and twenty-five (Maier 1975:8-9).

7 It is evident from Rabanus Maurus (776 or 784-856) that in the later Church specific ceremonial honour was given to the little martyrs on 28 December (Hrabanus Maurus Martyrologium mensis 12, dies 28, linea 282).

8 Eusebius Gallicanus Collectio Homiliarum Hom 11.27sqq: It is a conventional name given to a collection, made in Gaul, of 76 homilies containing material of disparate origin: Cyprian (2nd-3rd centuries), Novation (mid-third century) St. Ambrose (4th century), Augustine (4th), and Faustus of Riez (5th). It was systematized and revised by an unknown hand in the seventh century.

\section{Works consulted}

Braun, R 1964. Quodvultdeus livre des promesses et des predictions de dieu, vol II. Paris: Les editions du Cerf. (Sources chretiennes 102.)

Carpenter, M 1970. Kontakia of Romanos, Byzantine Melodist I: On the person of Christ. Columbia: University of Missouri Press.

Di Berardino, A \& Frend, W H C 1992. Encyclopedia of the early Church, Vols 1 \& 2. Cambridge: Clark.

Ferguson, E, (ed) et al 1990. Encyclopedia of Early Christianity. New York: Garland Publishing.

France, R T 1979. Herod and the children of Bethlehem. Novum Testamentum 21, 114.

Harris, W V 1994. Child-exposure in the Roman Empire. The Journal of Roman Studies, 84, 14.

Langer, W L 1974. Infanticide: A historical survey. History of Childhood Quarterly $13,355,363$.

Loader, J A (ed) 1979. Waarom sing ons in die kerk? 'n Nuwe lied vir die Here. Pretoria/Kaapstad: HAUM.

Maier, P L 1975. The Infant Massacre - History or Myth? Christianity Today 20, 8.

Mans, M J 1993. The problematic verb allentabit in the anonymous hymn 'Psalmus Responsorius'. Acta Patristica et Byzantina 4, 72-79. 
Migne, J-P (ed) s a. PG: Patrologiae cursus completus (series Graeca) Paris: Migne Migne, J-P (ed) s a. PL: Patrologiae cursus completus (series Latina) Paris: Migne. O'Brien Steinfels, M 1983. The scandal of the wholly innocent. Christianity and Crisis Dec 26, p 493.

Seneca 1960. Seneca's Tragedies. Loeb Classical Library.

Smith, W \& Cheetham, S (eds) 1908. Dictionary of Christian Antiquities Vol A-J. London: John Murray.

Tooley, M 1983. Abortion and Infanticide. Oxford: Clarendon Press.

Tupper, E F 1991. The Bethlehem Massacre - Christology against Providence? Review and Expositor 88, 409-410.

Westermarck, E 1906-1908. The killing of children, in The origin and development of moral ideas. London.

Williamson, L 1978. Infanticide: an anthropological analysis, in Kohl, M (ed), Infanticide and the value of life. Buffalo, New York: Prometheus Books. 